\title{
Editorial
}

\section{Cytokines in Induced Sputum: A Role for the Ratio of IL-6/IL-13 in the Differentiation of Asthma and Chronic Obstructive Pulmonary Disease?}

\author{
Federico L. Dente Elena Bacci Barbara Vagaggini Pierluigi Paggiaro \\ Respiratory Pathophysiology Section, Cardiothoracic Department, University Hospital of Pisa, Pisa, Italy
}

Asthma and chronic obstructive pulmonary disease (COPD) are both defined by the presence of airflow obstruction, airway remodeling, and airway inflammation, but the two conditions are clinically and pathophysiologically distinct $[1,2]$. Therefore, it is quite common to observe patients with asthma showing COPD-like phenotypes, and vice versa, making it a priority to search for optimal prevention, treatment, and management strategies for each case. Studies on the underlying inflammation demonstrate differences in the preponderance of inflammatory cells and mediators in each disease [3]. The main characteristic of obstructive diseases of the lung is airway inflammation, which appears differently but with significant overlaps between asthma and COPD [4].

In the last years, airway inflammation has been revealed to be a very complex process in lung disease. In the last 3 decades, the number and role of humoral mediators has become increasingly known. In this field, cytokines (more exactly, cytokine balance) represent messengers for communication in the tissues. Particularly, secreted proteins that bind to their specific receptors and play a role in communication among leukocytes are named interleukins (ILs). Since the discovery of IL-1 in 1977, approximately 200,000 published articles have referred to ILs. In a recent review, ILs 1-37 were examined [5]. The source of ILs is mainly the Thelper lymphocyte $\left(\mathrm{T}_{\mathrm{H}}\right)$. On the basis of IL profiles, CD41-naive T cells can differentiate into $\mathrm{T}_{\mathrm{H}} 1, \mathrm{~T}_{\mathrm{H}} 2, \mathrm{~T}_{\mathrm{H}} 9, \mathrm{~T}_{\mathrm{H}} 17, \mathrm{~T}_{\mathrm{H}} 22$, and T-follicular effector cells, and these $\mathrm{T}$-cell subsets can promote different types of inflammatory responses. For example, both $\mathrm{T}_{\mathrm{H}} 2$ and $\mathrm{T}_{\mathrm{H}} 17$ cytokines are thought to contribute to the pathogenesis of bronchial asthma. Evaluation of the relationship between different ILs provides a better measure of airway inflammation than measurement of each IL.

In this issue of Respiration, in the study of GrubekJaworska [6], IL-6 and IL-13 were chosen to evaluate the difference between asthma and COPD based on their balance. In fact, IL- 6 and IL-13 are known to be involved in respiratory diseases.

IL-13 is secreted predominantly by $\mathrm{T}_{\mathrm{H}} 2$ cells. It shares receptor components and many biological properties with IL-4. IL-13 receptors are expressed on mast cells, leukocyte subsets (eosinophils, monocytes, B cells), and structural cells (epithelial cells, fibroblasts, smooth muscle), all of which are considered relevant in asthma. The action of IL-13 on these cells is to stimulate processes that promote AHR, inflammation, and underlying airway structural changes including fibrosis and mucus hypersecretion, which are cardinal features of asthma [7]. IL-13 mRNA and protein levels are elevated in bronchial biop-

\section{KARGER}

Fax +4161306 1234

E-Mail karger@karger.ch

www.karger.com (c) 2012 S. Karger AG, Basel

0025-7931/12/0842-0098\$38.00/0

Accessible online at:

www.karger.com/res
Dr. Federico L. Dente

Respiratory Pathophysiology Section

Cardiothoracic Department, University Hospital of Pisa

IT-56100 Pisa (Italy)

Tel. +39 050995 403, E-Mail f.dente@ao-pisa.toscana.it 
sies, sputum, and bronchoalveolar lavage (BAL) fluid from asthmatics compared to control subjects $[8,9]$ and they are further increased in BAL samples from allergenchallenged asthmatics [10]. IL-13 protein expression in the lung is also correlated with both asthma severity and control. Mild steroid-naive asthmatics have upregulated IL-13 in the sputum compared to normals, as do severe asthmatics who have poor control despite the standard of care up to, and including, oral corticosteroids; moderate asthmatics controlled by inhaled corticosteroids do not have upregulated IL-13 expression [11]. Genetic polymorphisms in the IL-13 pathway are also associated with both atopy and asthma [12]; IL-13 Q130R has been associated with asthma, atopy, and raised serum IgE [13], activating the signalling IL-13 receptor $(\mathrm{R} \alpha 1)$ and downstream functions more efficiently, while binding to the decoy receptor $(\mathrm{R} \alpha 2)$ less efficiently, than wild-type IL-13 [14]. Given the range of cells involved in asthma on which IL13 is known to act, and the pathogenic functions ascribed to this IL, a significant role for IL-13 in asthma can be expected. Neutralization of IL-13 is a credible approach for the treatment of asthma and allergy. An anti-IL-13 Ab showed specific action in the nasal allergen challenge model, causing profound inhibition of nasal lining fluid IL-13 responses [15]. Moreover, IL-13 neutralizing IgG4 mAb CAT-354 [16] in an animal model and IgG1 Ab neutralizing IL-13 bioactivity in a human model [17] are advancing toward clinical development, also demonstrating controversial results.

IL-6 is a pro-inflammatory cytokine that is secreted by the stimuli on $\mathrm{T}$ cells, being able to induce development of the inflammation by means of $\mathrm{T}_{\mathrm{H}} 17$ and $\mathrm{T}_{\mathrm{H}} 22$ cells by amplification of IL- 6 production. This inflam- matory mechanism provokes the neutrophilic reaction to fight, firstly, extracellular pathogens [5]. IL-6 is responsible for modulation of the synthesis of acute phase proteins such as C-reactive protein (CRP) [5] and plasma fibrinogen [18] in many models of inflammation in many tissues of the entire body. On this basis, IL- 6 could be considered as a useful biomarker of COPD, a disease with systemic inflammation as marked by increased CRP. IL-6 is not exclusive to a single lung disease. In patients with asthma, similarly to IL-8, sputum IL-6 levels have an inverse relationship with $\mathrm{FEV}_{1}$ [19]. In a prospective crosssectional study in patients with mild asthma it was reported that sputum IL-6 levels correlated inversely with post-bronchodilator $\mathrm{FEV}_{1}$ [20]. Other reports demonstrated a negative correlation between $\mathrm{FEV}_{1}$ and sputum IL- 6 and IL-8 levels and a weak correlation with asthma control [19]. Moreover, IL-6 proteins were found to be significantly increased in subjects with chronic rhinosinusitis with nasal polyps [21].

IL-13 and IL- 6 are not specific for a single disease, but they show different relationships with asthma and COPD. A strong link between IL-13 and airway inflammation has been demonstrated in allergy and mainly in asthma, but no link has been found between IL-13 and pulmonary function levels. IL-6 is associated with systemic and local inflammation in COPD but is mainly related to pulmonary function. The balance between these two ILs increases the sensibility and specificity of the measures of airway inflammation. This contributes to the phenotypic characterization of obstructive pulmonary diseases which represents, presently and in the future, an important target in the management and treatment of respiratory diseases.

\section{References}

1 National Heart Lung and Blood Institute: Expert Panel Report 3: Guidelines for the Diagnosis and Management of Asthma. NIH Publication No. 07-4051. Bethesda, NIH, 2007.

-2 Rabe KF, Hurd S, Anzueto A, Barnes PJ, Buist SA, Calverley P, Fukuchi Y, Jenkins C, Rodriguez-Roisin R, van Weel C, Zielinski J; Global Initiative for Chronic Obstructive Lung Disease: Global strategy for the diagnosis, management, and prevention of chronic obstructive pulmonary disease: GOLD executive summary. Am J Respir Crit Care Med 2007;176:532-555.
3 Dima E, Rovina N, Gerassimou C, Roussos C, Gratziou C: Pulmonary function tests, sputum induction, and bronchial provocation tests: diagnostic tools in the challenge of distinguishing asthma and COPD phenotypes in clinical practice. Int $\mathrm{J}$ Chron Obstruct Pulm Dis 2010;5:287-296.

4 Fabbri LM, Romagnoli M, Corbetta L, Casoni G, Busljetic K, Turato G, Ligabue G, Ciaccia A, Saetta M, Papi A: Differences in airway inflammation in patients with fixed airflow obstruction due to asthma or chronic obstructive pulmonary disease. Am J Respir Crit Care Med 2003;167:418-424.
5 Akdis M, Burgler S, Crameri R, Eiwegger T, Fujita H, Gomez E, Klunker S, Meyer N, O'Mahony L, Palomares O, Rhyner C, Quaked N, Schaffartzik S, Van De Veen W, Zeller S, Zimmermann M, Akdis CA: Interleukins, from 1 to 37 , and interferon- $\gamma$ : receptors, functions, and roles in diseases. J Allergy Clin Immunol 2011;127:701-721.

6 Grubek-Jaworska H, Paplińska M, Hermanowicz-Salamon J, Białek-Gosk K, Dąbrowska M, Grabczak E, DomagałaKulawik J, Stępień J, Chazan R: IL-6 and IL13 in induced sputum of COPD and asthma patients: correlation with respiratory tests. Respiration 2012;84:101-107. 
7 Hershey GK: IL-13 receptors and signaling pathways: an evolving web. J Allergy Clin Immunol 2003;111:677-690.

-8 Humbert M, Durham SR, Kimmitt P, Powell N, Assoufi B, Pfister R, Menz G, Kay AB, Corrigan CJ: Elevated expression of messenger ribonucleic acid encoding IL-13 in the bronchial mucosa of atopic and nonatopic subjects with asthma. J Allergy Clin Immunol 1997;99:657-665.

-9 Komai-Koma M, McKay A, Thomson L, McSharry C, Chalmers GW, Liew FY, et al: Immuno-regulatory cytokines in asthma: IL-15 and IL-13 in induced sputum. Clin Exp Allergy 2001;31:1441-1448.

-10 Prieto J, Lensmar C, Roquet A, van der Ploeg I, Gigliotti D, Eklund A, Grunewald J: Increased interleukin-13 mRNA expression in bronchoalveolar lavage cells of atopic patients with mild asthma after repeated lowdose allergen provocations. Respir Med 2000;94:806-814.

11 Saha SK, Berry MA, Parker D, Siddiqui S, Morgan A, May R, Monk P, Bradding P, Wardlaw AJ, Pavord ID, Brightling CE: Increased sputum and bronchial biopsy IL-13 expression in severe asthma. J Allergy Clin Immunol 2008;121:685-691.

12 Howard TD, Whittaker PA, Zaiman AL, Koppelman GH, Xu J, Hanley MT, Meyers DA, Postma DS, Bleecker ER: Identification and association of polymorphisms in the interleukin-13 gene with asthma and atopy in a Dutch population. Am J Respir Cell Mol Biol 2001;25:377-384.
13 Heinzmann A, Mao XQ, Akaiwa M, Kreomer RT, Gao PS, Ohshima K, Umeshita R, Abe Y, Braun S, Yamashita T, Roberts MH, Sugimoto R, Arima K, Arinobu Y, Yu B, Kruse S, Enomoto T, Dake Y, Kawai M, Shimazu S, Sasaki S, Adra CN, Kitaichi M, Inoue $\mathrm{H}$, Yamauchi $\mathrm{K}$, Tomichi N, Kurimoto F, Hamasaki N, Hopkin JM, Izuhara K, Shirakawa T, Deichmann KA: Genetic variants of IL-13 signalling and human asthma and atopy. Hum Mol Genet 2000;9: 549-559.

14 Vladich FD, Brazille SM, Stern D, Peck ML, Ghittoni R, Vercelli D: IL-13 R130Q, a common variant associated with allergy and asthma, enhances effector mechanisms essential for human allergic inflammation. J Clin Invest 2005;115:747-754.

15 Nicholson GC, Kariyawasam HH, Tan AJ, Hohlfeld JM, Quinn D, Walker C, Rodman D, Westwick J, Jurcevic S, Kon OM, Barnes PB, Krug N, Hansel TT: The effects of an anti-IL-13 mAb on cytokine levels and nasal symptoms following nasal allergen challenge. J Allergy Clin Immunol 2011;128: 800-807.

16 May RD, Monk PD, Cohen ES, Manuel D, Dempsey F, Davis NH, Dodd AJ, Corkill DJ, Woods J, Joberty-Candotti C, Conroy LA, Koentgen F, Martin EC, Wilson R, Brennan N, Powell J, Anderson IK: Preclinical development of CAT-354, an IL-13-neutralising antibody, for the treatment of severe uncontrolled asthma. $\mathrm{Br} \mathrm{J}$ Pharmacol DOI: 10.1111/j.1476-5381.2011.01659.x.
17 Gauvreau GM, Boulet LP, Cockcroft DW, FitzGerald JM, Carlsten C, Davis BE, Deschesnes F, Duong ML, Durn BL, Howie KJ, Hui L, Kasaian MT, Killian KJ, Strinich TX, Watson RM, Y N, Zhou S, Raible SD, O'Byrne PM: Effects of interleukin-13 blockade on allergen-induced airway responses in mild atopic asthma. Am J Respir Crit Care Med 2011;183:1007-1014.

18 Donaldson GC, Seemungal TA, Patel IS, Bhowmik A, Wilkinson TM, Hurst JR, MacCallum PK, Wedzicha JA: Airway and systemic inflammation and decline in lung function in patients with COPD. Chest 2005; 128:1995-2004.

19 Morjaria JB, Babu KS, Vijayanand P, Chauhan AJ, Davies DE, Holgate ST: Sputum IL-6 concentrations in severe asthma and its relationship with FEV1. Thorax 2011;66:537.

-20 Dixon AE, Raymond DM, Suratt BT, Bourassa LM, Irvin CG: Lower airway disease in asthmatics with and without rhinitis. Lung 2008; 186:361-368.

21 Peters AT, Kato A, Zhang N, Conley DB, Suh L, Tancowny B, Carter D, Carr T, Radtke M, Hulse KE, Seshadri S, Chandra R, Grammer LC, Harris KE, Kern R, Schleimer RP: Evidence for altered activity of the IL- 6 pathway in chronic rhinosinusitis with nasal polyps. J Allergy Clin Immunol 2010;125:397-403. 